\title{
Lectotypification in Stellaria (Caryophyllaceae)
}

\author{
Satish Chandra and D.S. Rawat* \\ Department of Biological Sciences, College of Basic Sciences and Humanities, \\ G.B. Pant University of Agriculture and Technology, Pantnagar - 263145, Uttarakhand, India. \\ *E-mail: drds_rawat@yahoo.com
}

\begin{abstract}
Three names in Stellaria, viz., S. semivestita Edgew., S. subumbellata Edgew. and S. webbiana (Benth. ex G. Don) Edgew. \& Hook.f. are lectotypified here.
\end{abstract}

Keywords: Lectotype, Stellaria, Uttarakhand

\section{Introduction}

The genus Stellaria L. comprises of c. 120 species in the world (Bittrich, 1993; Mabberley, 2008). In India, the genus is represented by 19 species, of which 13 are known from the Western Himalaya (Majumdar, 1993; Chandra Sekar \& Srivastava, 2007; Pusalkar \& Srivastava, 2015). During the present study on the family Caryophyllaceae of the Western Himalaya, it was found that three names in Stellaria, viz., S. semivestita Edgew., S. subumbellata Edgew. and S. webbiana (Benth. ex G. Don) Edgew. \& Hook.f. need to be lectotypified. After a thorough scrutiny of literature and examination of original specimens all these names are lectotypified and the designated specimen images are provided here.

Stellaria semivestita Edgew. in Hook.f., Fl. Brit. India 1: 230. 1874.

Lectotype(designated here):INDIA,Uttarakhand, Kumaon, Lohooghat, $5500 \mathrm{ft}$, May1845, T. Thomson s.n. (K000723661, image!, on the upper part of the sheet); Kumaon, Dadoo ka Taola, $8000 \mathrm{ft}$, June 1845, T. Thomson s.n. (isolecto, K000723662, image!).

Fig. 1

Edgeworth (1874) described Stellaria semivestita based on specimens (K000723661, K000723662) collected by T. Thomson in 1845 from Lohooghat (presently Lohaghat) and Dadoo ka Taola areas of Kumaon region, respectively. The two specimens are mounted on the same sheet, of the two the one bears the barcode, K000723661, matches well with the description given in protologue, the same is designated here as the lectotype, and K000723662 is considered as isolectotype.

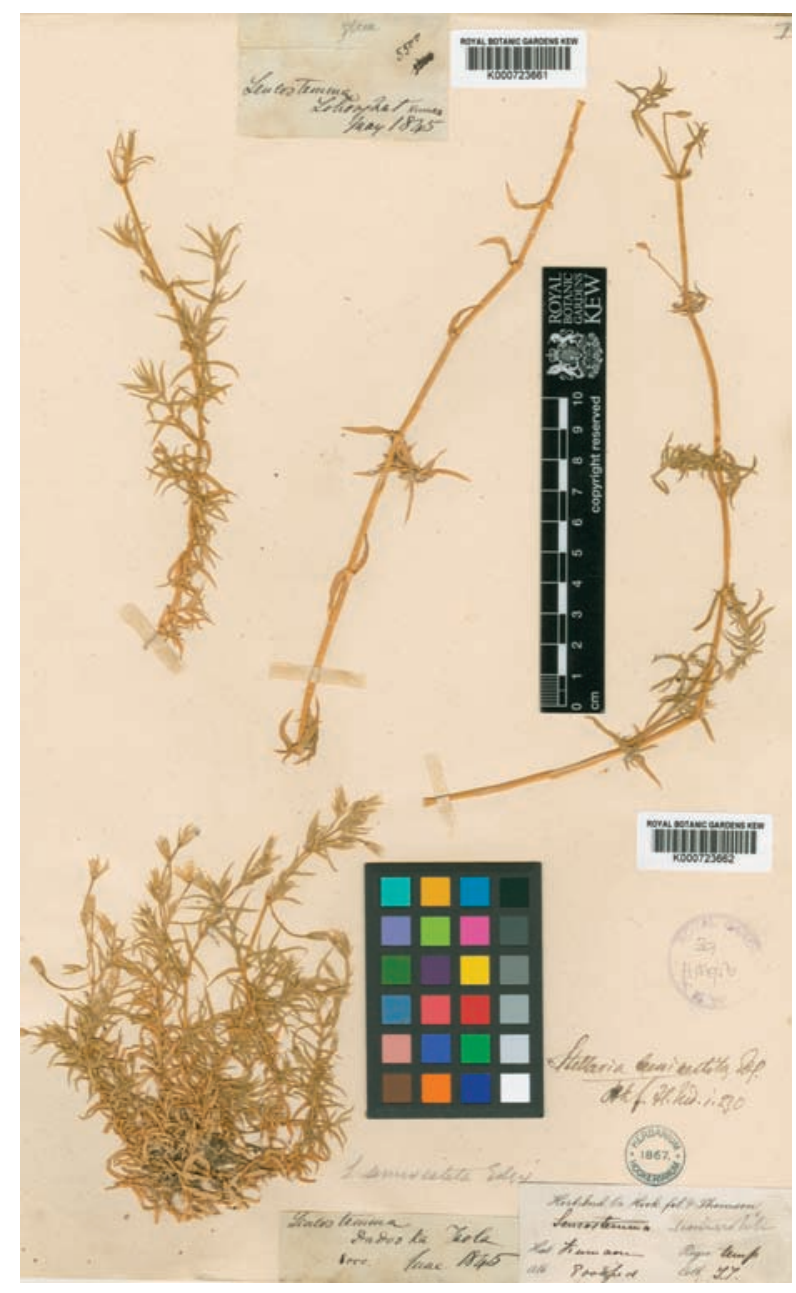

Fig. 1. Lectotype of Stellaria semivestita Edgew. (T. Thomson s.n., K000723661). 


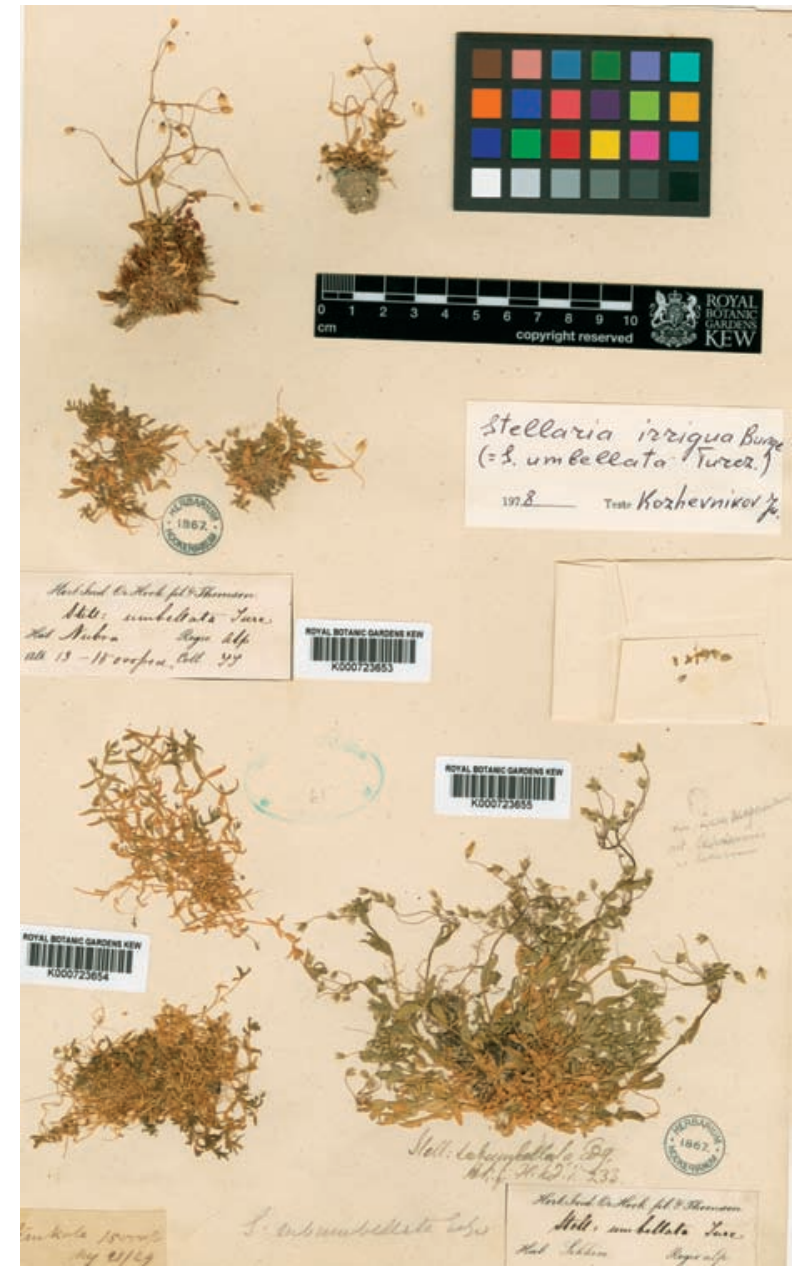

Fig. 2. Lectotype of Stellaria subumbellata Edgew. (Thomson s.n., K000723653).

Stellaria subumbellata Edgew. in Hook.f., Fl. Brit. India 1: 233. 1874.

Lectotype (designated here): TIBET, Western Tibet, Nubra valley, $13000-15000 \mathrm{ft}, \mathrm{T}$. Thomson s.n. (K000723653, image!, specimen mounted on the upper half of the sheet; isolecto, P05436871, image!).

Fig. 2

Edgeworth (1874) described Stellaria subumbellata based on the specimens collected by T. Thomson and J.D. Hooker in 1849 from Nubra valley, Western Tibet and interior of Sikkim, respectively. Thomson \& Hooker initially identified them as S. umbellata, but later, Edgeworth (1874) found the specimens differ from S. umbellata by having few bracts and strongly granulated seeds and hence described as a new species. All these original specimens are housed at K (K000723653, K000723651, K000723652, K000723650，K000723654，K000723655) and

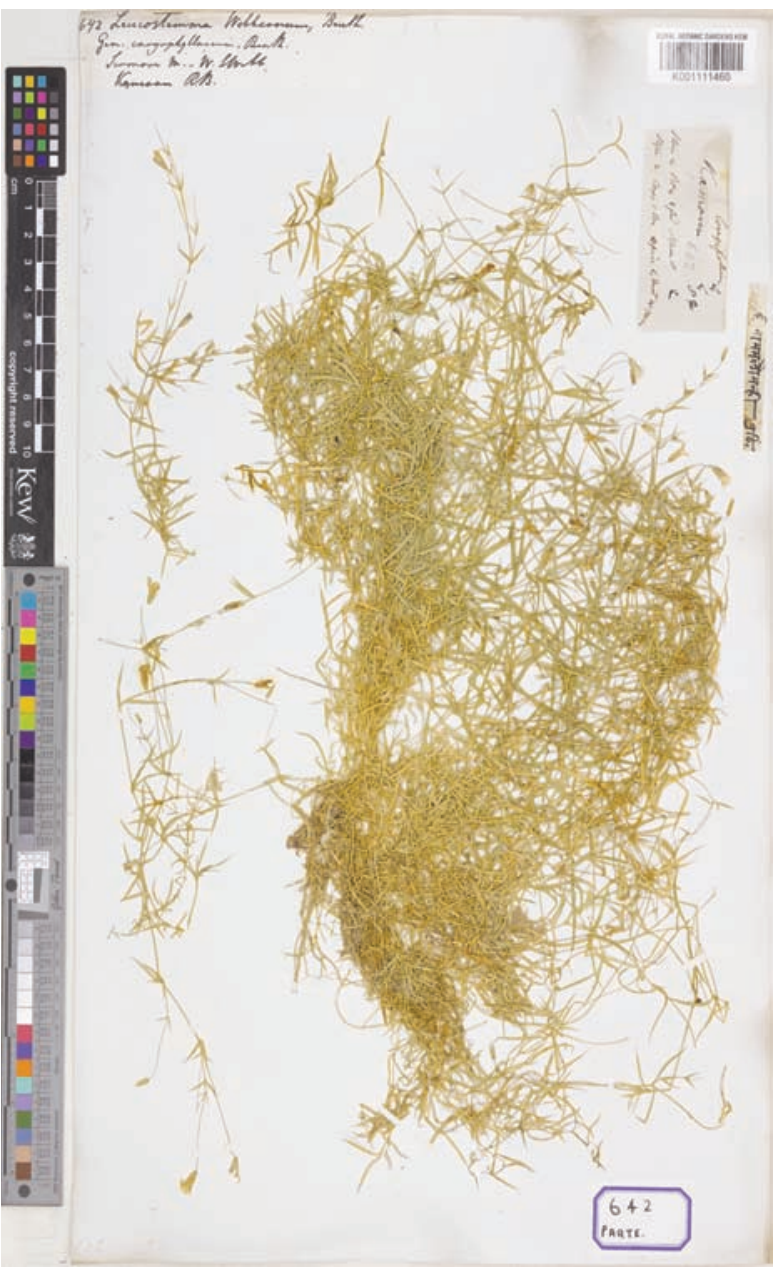

Fig. 3. Lectotype of Stellaria webbiana (Benth. ex G. Don) Edgew. \& Hook.f. (N. Wallich s.n., K001111460).

P (P05436871, P05436873, P05436786). Of these, K000723653 is designated here as the lectotype for the name as it agrees well with the description provided in the protologue.

Stellaria webbiana (Benth. ex G. Don) Edgew. \& Hook.f. in Hook.f., Fl. Brit. India 1: 230. 1874. Leucostemma webbianum Benth. ex G. Don, Gen. Hist. 1: 449. 1831.

Lectotype (designated here): INDIA, Uttarakhand, Kumaon, 1830, N. Wallich s.n. (K001111460, image!; isolecto, K001111461, image!; K000723660, image!).

Fig. 3

Leucostemma webbianum Benth. ex G. Don was described based on Wallich's Catalogue No. 642 collected from Kumaon to Sirmor area of Western Himalaya, India by Wallich. Edgeworth \& Hooker (1874) transferred it under Stellaria. There are 
three original materials (K001111460, K001111461, K000723660) housed at K, and all of them were collected from Kumaon, India. Of which, the specimen bears barcode, K001111460 contains information written in local language as 'नाम मालूम नहीं पढ़ी' means 'name not known' and fits well with the original description given in the protologue, hence it is designated here as the lectotype.

\section{Acknowledgements}

The authors are thankful to the Board of Trustees of Royal Botanic Gardens, Kew, for permitting to publish the images of specimens. Authors are also thankful to anonymous reviewers, for their suggestions and necessary corrections.

\section{Literature Cited}

Bittrich, V. 1993. Introduction to Centrospermae. In: Kubitzki, K., Rohwer, J.G. \& V. Bittrich (eds.), The families and genera of vascular plants. Vol. 2. Magnoliid, Hamamelid, and Caryophyllid families. Springer Science, Germany. pp. 13-19.
Chandra Sekar, K. \& S.K. Srivastava 2007. Stellaria pinvalliaca (Caryophyllaceae), a new species from India. Feddes Repert. 118: 20-23.

Edgeworth, M.P. 1874. Caryophyllaceae. In: Hooker, J.D. (ed.), The Flora of British India. Vol. 1. L. Reeve \& Co., London. pp. 212-246.

Mabberley, D.J. 2008. Mabberley's Plant-Book: A portable dictionary of plants, their classifications, and uses. Third Edition. Cambridge University Press, Cambridge.

Majumdar, N.C. 1993. Caryophyllaceae. In: Sharma, B.D. \& N.P. Balakrishnan, (eds.), Flora of India. Vol. 2 (Papaveraceae-Caryophyllaceae). Botanical Survey of India, Calcutta. pp. 503-595.

Pusalkar, P.K. \& S.K. Srivastava 2015. Stellaria devendrae sp. nov. (Caryophyllaceae) from Western Himalaya, India. Nordic J. Bot. 33: 385-388.

Received: 17.12.2015

Revised and Accepted: 20.12.2017 